\title{
Penerapan Kartu Pintar Fisiologi Manusia dalam Metode Pembelajaran Cooperative Learning
}

\author{
Mutiara Herawati*, Suci Hanifah \\ Jurusan Farmasi, Fakultas MIPA, Universitas Islam Indonesia, Yogyakarta 55534, INDONESIA \\ *Email korespondensi : mutiara.herawati@uii.ac.id
}

(Submit 15/03/2019, Revisi 05/09/2019, Diterima 20/12/2019)

\begin{abstract}
Abstrak
Semula metode pembelajaran berpusat pada dosen (Teacher Centre Learning), namun kini metode pembelajaran mulai diubah menjadi berpusat pada siswa (SCL/Student Centre Learning) yang mana keduanya memiliki keuntungan dan kekurangan masingmasing. Metode pembelajaran cooperative learning dengan penerapan jigsaw diharapkan dapat meningkatkan aspek kognitif, psikomotor dan afektif mahasiswa. segala aktivitas pembelajaran didominasi oleh keterlibatan mahasiswa didalamnya. Penelitian ini bertujuan untuk mengetahui penerapan kartu pintar fisiologi manusia dalam metode pembelajaran Cooperative Learning sehingga dapat meningkatkan motivasi dan strategi dalam belajar mahasiswa, pemahaman mahasiswa serta kelulusan dengan nilai $\geq \mathrm{C}$ mahasiswa. Proses pembelajaran dimodifikasi dengan penggunaan google classroom untuk meningkatkan pemahaman mahasiswa selama menerima materi. Digunakan pula kuesioner Motivated Strategies for Learning Questionnaire (MSLQ) yang merupakan alat ukur mandiri yang digunakan untuk mengetahui orientasi motivasi mahasiswa dalam belajar dan dapat digunakan untuk mengetahui strategi mahasiswa dalam belajar. Berdasarkan dari pertanyaan kuesioner didapatkan nilai rata-rata diatas 3 (skala maksimal 4) yang artinya bahwa metode pembelajaran yang diterapkan pada mahasiswa membuat mahasiswa memiliki kemampuan untuk diskusi, mencapai tujuan pembelajaran, menstimulasi mahasiswa untuk belajar dan meningkatkan minat serta pemahaman dalam mempelajari mata kuliah fisiologi manusia. Disamping itu, diketahui bahwa kelompok perlakuan 62,15 memiliki nilai paling tinggi dibandingkan dengan kelompok kontrol 59.75 serta meningkatkan kelulusan mahasiswa fisiologi manusia dari baseline $50 \%$ menjadi $60 \%$. Metode pembelajaran ini efektif meningkatkan nilai rata-rata akhir.
\end{abstract}

Kata kunci: kartu bergambar, SCL, fisiologi manusia

\section{Outline}

- Pendahuluan

- Metode

- Hasil dan Pembahasan

- Kesimpulan

- Ucapan Terima Kasih dan Legal Responsibility

- Daftar Pustaka 


\section{Pendahuluan}

Mata kuliah Fisiologi Manusia adalah salah satu Mata Kuliah Keilmuan dan Ketrampilan yang menjadi dasar ilmu dan prasyarat mata kuliah di bidang farmakologi dan farmakoterapi. Berdasarkan pada visi dan misi program studi dan universitas untuk menciptakan lulusan yang unggul dalam keilmuan dan keislaman, maka kompetensi lulusan mata kuliah fisiologi manusia diharapkan menguasai knowledge dan konsep tentang sistem pada manusia, memahami anatomi dan fisiologi, serta proses yang terkait dalam setiap sistem yang dipelajari dengan tetap menjiwai nilai-nilai islami dalam kehidupan sehari-hari.

Metode pembelajaran yang sudah dilakukan sebelumnya adalah perkuliahan dengan menggunakan metode pembelajaran konvensional. Komponen penilaian terdiri atas kuis, tugas mind map, dan ujian. Masih banyaknya mahasiswa yang mengulang mata kuliah ini (nilai kelulusan $\geq \mathrm{C}$ ) menunjukkan bahwa perlu diidentifikasi metode pembelajaran yang tepat dan dapat diaplikasikan pada mata kuliah fisiologi manusia untuk mahasiswa farmasi.

Kondisi mahasiswa yang cenderung sekedar menghafal, saat diberikan materi perkuliahan cenderung pasif dan kedalaman pemahaman yang masih kurang, sehingga disimpulkan bahwa mahasiswa belum memahami arti penting dalam setiap pembelajaran fisiologi manusia. Hal ini menunjukkan bahwa kompetensi dan indikator pencapaian pembelajaran fisiologi manusia belum tercapai, sehingga perlu dikembangkan suatu metode pembelajaran yang dapat mengubah prespektif mahasiswa dalam mempelajari fisiologi manusia yang dapat meningkatkan kualitas pembelajaran.

Mahasiswa yang terlibat dalam pembelajaran fisiologi manusia adalah mahasiswa semester dua yang perlu diketahui motivasi dalam strategi belajar mereka. Oleh karena itu, melalui hibah ini, dosen pengampu menggunakan Motivated Strategies for Learning Questionnaire (MSLQ) yang merupakan alat ukur mandiri yang digunakan untuk mengetahui orientasi motivasi mahasiswa dalam belajar dan dapat digunakan untuk mengetahui strategi mahasiswa dalam belajar. Sehingga dengan adanya hasil dari MSLQ diharapkan dapat sejalan dengan harapan mahasiswa dalam pencarian strategi belajar dalam memahami matakuliah ini.

Perubahan paradigma dari metode pembelajaran TCL (Teacher Center Learning) menjadi SCL (Student Center Learning) diharapkan dapat mengubah kualitas mahasiswa dalam proses pembelajaran. SCL menjadikan dosen sebagai fasilitator dan motivator yang menitikberatkan interaksi dengan mahasiswa pada method of inquiry dan discovery sehingga mahasiswa dapat menunjukkan kinerja yang kreatif sehingga dapat meningkatkan aspek kognitif, psikomotor dan afektif mahasiswa.

Ragam model pembelajaran SCL memiliki keunggulan masing-masing dalam pencapaian peningkatan kualitas pembelajaran mahasiswa. Inovasi model pembelajaran yang dipilih dalam strategi pembelajaran mata kuliah fisiologi manusia adalah cooperative learning yang dimodifikasi dengan kartu pintar bergambar. Hal-hal yang harus dilakukan dosen dalam model pembelajaran ini adalah merancang pembuatan kartu pintar bergambar yang bertujuan memudahkan mahasiswa mengingat 
bentuk dan struktur fisiologi manusia serta memonitor proses belajar dan hasil belajar mahasiswa. Sehingga selain dapat meningkatkan kualitas belajar mahasiswa, metode ini mampu meningkatkan kemampuan mahasiswa dalam belajar sehingga mahasiswa tidak kesulitan dalam menghafal, bahkan diharapkan dengan inovasi pembelajaran ini mahasiswa menjadi tertarik untuk mempelajari mata kuliah fisiologi manusia dengan mudah dan menyenangkan.

Oleh karena itu, diharapkan dengan inovasi metode pembelajaran cooperative learning dengan metode kartu pintar bergambar dapat meningkatkan pemahaman mahasiswa pada mata kuliah fisiologi manusia.

\section{Metode}

Program ini telah dilaksanakan pada 1 Maret - 8 Juli 2017. Mahasiswa yang terlibat dalam hibah ini sebanyak 100 mahasiswa yang dibagi menjadi 2 kelas masing-masing 50 mahasiswa masuk kedalam kelompok perlakuan dan 50 mahasiswa dalam kelompok kontrol. Adapun tahapan implementasi metode pembelajaran dibagi kedalam 3 (tiga) tahap utama sebagai berikut:

1) Persiapan perkuliahan yang terdiri dari:

a. Pembuatan materi perkuliahan, kartu bergambar, tugas, kuis, review terhadap materi perkuliahan yang akan diupload di google classroom

b. Membuat instrumen kuesioner aspek penilaian dan menjelaskan feedback yang harus dilakukan oleh setiap mahasiswa.

c. Penerimaan asisten dengan persyaratan merupakan mahasiswa aktif farmasi yang telah menempuh matakuliah fisiologi manusia dengan nilai minimal $\mathrm{B}$.

2) Pelaksanaan perkuliahan

Terdapat 2 kelas dengan masing-masing kelas berisi 50 mahasiswa. Pembagian kelompok berdasarkan kelas. Kelompok perlakuan pada kelas A dan kelompok kontrol (belajar secara konvensional) pada kelas B.

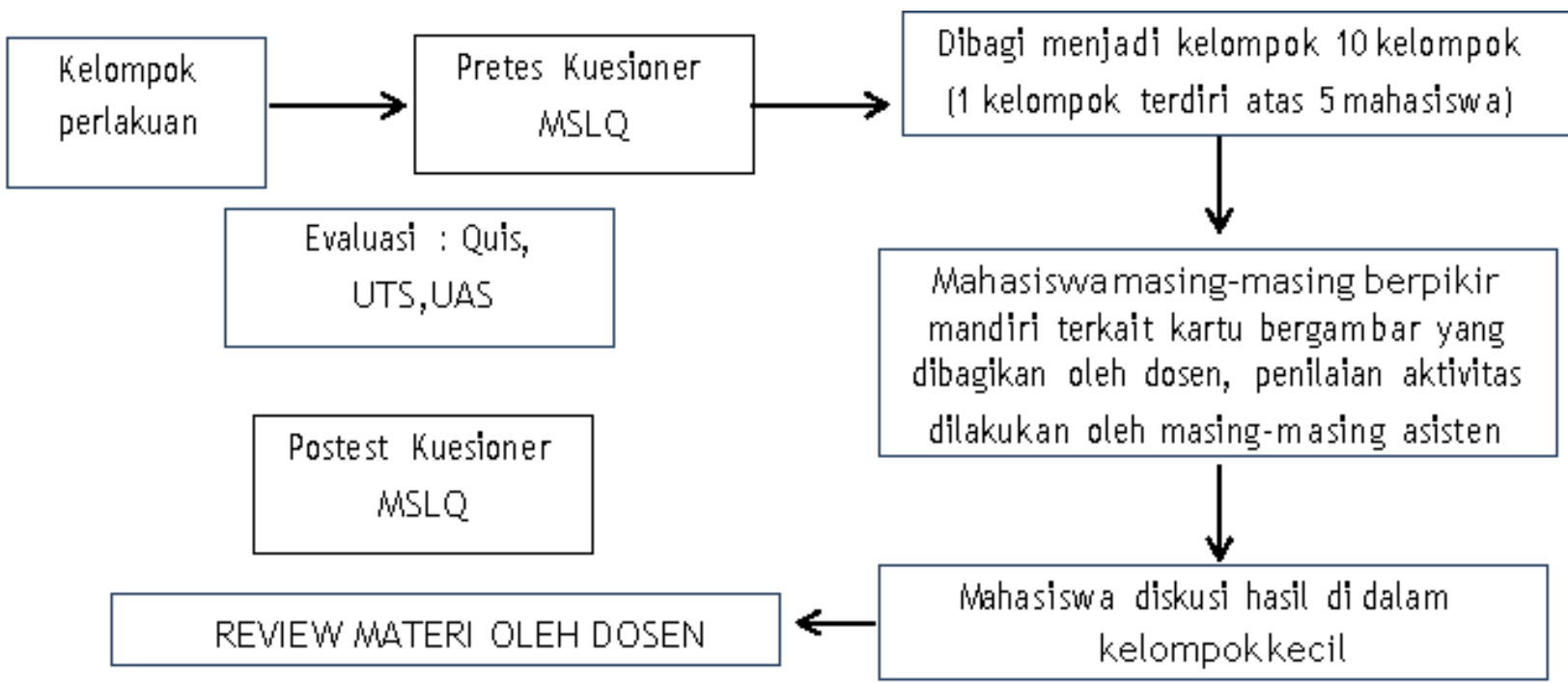

Gambar 1. Alur Penelitian Pengajaran Fisiologi Manusia 


\section{Hasil dan Pembahasan}

Mendokumentasikan proses dan hasil yang dicapai dengan menggunakan model pembelajaran yang diusulkan.

Kelas A merupakan kelompok Perlakuan
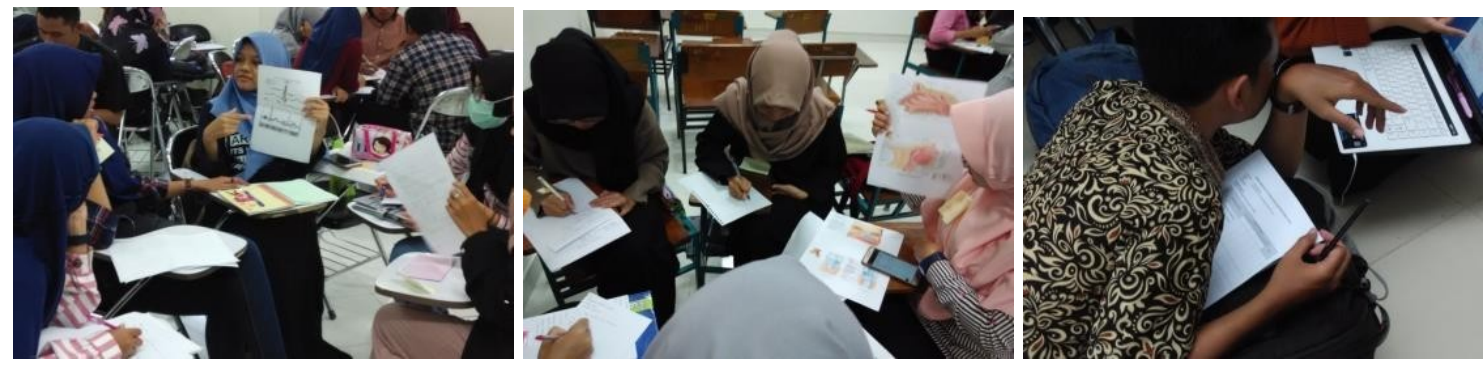

Gambar 2. Kondisi diskusi kelompok perlakuan di ruang kelas
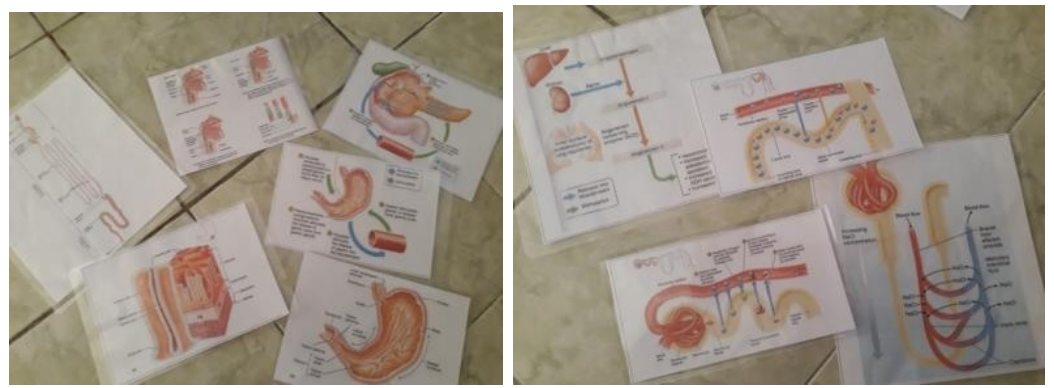

Gambar 3. Contoh Kartu Fisiologi Manusia Bergambar

Mahasiswa kelompok perlakuan dan kontrol mendapatkan tools kusioner yang sama yang diukur pada awal dan akhir pertemuan perkuliahan. Tools tersebut adalah MSQL. Kuesioner tersebut menanyakan tentang kebiasan mahasiswa dalam belajar, keterampilan dan motivasi belajar di kelas. Sehingga diharapkan dapat diidentifikasi awal bagaimana harapan dan strategi belajar mahasiswa di dalam kelas yang merupakan cerminan harapan mahasiswa terhadap mata kuliah tersebut. Berikut merupakan nilai dari komponen MSQL.

Tabel 1. Nilai rata-rata pada komponen penilaian Motivated Strategies for Learning Questionnaire (MSLQ)

\begin{tabular}{|c|c|c|c|c|c|c|c|}
\hline \multirow{3}{*}{ No } & \multirow{3}{*}{ Value Component } & \multicolumn{4}{|c|}{ Nilai Rata-rata } & \multirow{2}{*}{\multicolumn{2}{|c|}{ Delta (Posttest - Pretes }} \\
\hline & & \multicolumn{2}{|c|}{ Pretest } & \multicolumn{2}{|c|}{ Posttest } & & \\
\hline & & Perlakuan & Kontrol & Perlakuan & Kontrol & Perlakuan & Kontrol \\
\hline 1 & $\begin{array}{ll}\text { Intrinsic } & \text { Goal } \\
\text { Orientation } & \end{array}$ & 4.83 & 5.45 & 5.26 & 5.24 & 0.43 & -0.21 \\
\hline 2 & $\begin{array}{ll}\text { Extrinsic } & \text { Goal } \\
\text { Orientation } & \end{array}$ & 5.87 & 6.21 & 5.92 & 6.09 & 0.05 & -0.12 \\
\hline 3 & Task Value & 5.12 & 5.72 & 5.80 & 5.56 & 0.68 & -0.61 \\
\hline
\end{tabular}




\section{i. Intrinsic Goal Orientation}

Pertanyaan yang diajukan pada komponen ini adalah

1) Dalam kelas seperti ini saya lebih menyukai materi kuliah yang benar- benar menantang sehingga saya dapat mempelajari hal-hal baru (nomer soal 1)

2) Saya lebih suka materi kuliah yang membangkitkan keingintahuan saya, walaupun sulit untuk dipelajari (nomer soal 16)

3) Hal yang paling memuaskan untuk saya dalam sebuah kuliah adalah mencoba untuk sebisa mungkin benar-benar mengerti isinya (nomer soal 22)

4) Ketika saya mempunyai kesempatan, saya memilih tugas kuliah yang dapat saya peroleh pelajaran darinya, walaupun hal ini tidak menjamin mendapat nilai yang bagus (nomer soal 24)

\section{ii. Extrinsic Goal Orientation}

1) Mendapat nilai-nilai bagus dalam kuliah-kuliah saya adalah hal yang paling memuaskan untuk saya sekarang ini (nomer soal 7)

2) Hal yang paling penting untuk saya saat ini adalah memperbaiki rata- rata nilai keseluruhan saya, sehingga perhatian utama saya adalah mendapat nilai bagus dalam kulian-kuliah saya (nomer soal 11)

3) Bila saya bisa, saya mau mendapat nilai yang lebih baik dalam kuliah- kuliah saya dibanding kebanyakan mahasiswa lainnya (nomer soal 13)

4) Saya ingin melakukan kuliah saya dengan baik karena penting untuk menunjukkan kemampuan saya pada keluarga saya, teman, atasan dan yang lainnya (nomer soal 30)

\section{iii. Task Value}

1) Saya pikir saya akan dapat menggunakan apa yang saya pelajari di suatu kuliah di kuliah-kuliah lain yang saya ambil (nomer soal 4)

2) Penting bagi saya untuk belajar materi dalam kuliah saya (nomer soal 10)

3) Saya sangat tertarik pada isi kuliah saya (nomer soal 17)

4) Saya pikir materi dikuliah saya umumnya berguna untuk saya pelajari (nomer soal 23)

5) Saya umumnya menyukai bahan pelajaran kuliah saya (nomer soal 26)

6) Mengerti bahan pelajaran kuliah sangat penting untuk saya (nomer soal 27)

Pada pertanyaan diatas menggambarkan faktor intrinsik (dari dalam diri) mahasiswa terhadap motivasi dan strategi belajarnya. Didapatkan nilai rata-rata saat pretest kelompok kontrol lebih tinggi dibandingkan kelompok perlakuan. Meskipun demikian selisih nilai antar pretest dan postest terdapat nilai positif pada kelompok perlakuan yang menunjukkan bahwa adanya perlakuan terhadap strategi belajar kartu bergambar fisiologi manusia dapat meningkatkan motivasi mahasiswa dalam belajar.

Penjelasan pada tabel 1 mengenai nilai rata-rata pada komponen kuesioner MSLQ dilihat pada selisih nilai posttest dan pretest. Pada kelompok intervensi diketahui nilai positif menandakan bahwa adanya intervensi pada pembelajaran (kartu pintar fisiologi manusia) menandakan mahasiswa mengalami peningkatan dalam motivasi pembelajaran dalam fisiologi manusia dalam aspek intrinsik, ekstrinsik dan task value. 
Tabel 2. Rata-rata dan huruf nilai akhir Fisiologi manusia

\begin{tabular}{|c|c|c|c|}
\hline \multicolumn{4}{|c|}{ Rata-rata Nilai } \\
\hline Intervensi & Kontrol & Baseline & /2016 \\
\hline 62.15 & 59.75 & 60.90 & C \\
\hline
\end{tabular}

Pada tabel 2 diketahui bahwa terdapat perbedaan antara nilai kelompok perlakuan dengan kelompok kontrol. Dari data tersebut dapat diketahui bahwa kelompok perlakuan memiliki nilai paling tinggi dibandingkan dengan kelompok kontrol dan nilai mahasiswa angkatan 2015. Oleh karena itu, metode pembelajaran ini efektif meningkatkan nilai rata-rata akhir. Nilai rata-rata antara angkatan 2015 dan 2016 dapat dibandingkan dengan melihat nilai rata-rata IP sementara dikedua angkatan tersebut pada waktu dimana telah menempuh matakliah fisiologi manusia.

\section{Kesimpulan}

Metode pembelajaran berbasis SCL dengan bantuan kartu bergambar fisiologi manusia dapat meningkatkan motivasi dan strategi mahasiswa dalam belajar serta meningkatkan kelulusan dan pemahaman mahasiswa. Oleh karena itu, proses belajar secara aktif meningkatkan capaian tujuan pembelajaran.

\section{Ucapan Terima Kasih dan Legal Responsibility}

Terima kasih kepada Badan Pengembangan Akademik Universitas Islam Indonesia yang telah memberikan dana penelitian Hibah Pengajaran Reguler untuk mata kuliah Fisiologi Manusia.

\section{Daftar Pustaka}

1. Santos, Cooperative Learning: Penerapan Teknik Jigsaw Dalam Pembelajaran., Buletin Pelangi Pendidikan. Vol. 1. No. 1. 1999, hal 6.

2. Karen L.Medsker and Kristina M. Holdsworth, 2001,h.287.

3. Allchin D. 2013. Problem- and case-based learning in science: an introduction to distinctions, values, and outcomes. CBE-Life Sciences Education. 12:364-372

4. Fingerson,L., Culley, A., Collaborators in teaching and learning : undergraduate teaching assistant in the classroom, Teaching sociology, 29 (3), $299-315$. 